\title{
KORELASI TINGKAT KEPERCAYAAN DIRI TERHADAP PRESTASI BELAJAR MAHASISWA DI IAIN SYEKH NURJATI CIREBON (Studi Pada Calon Pendidik Matematika)
}

\author{
Uun Badriyah dan Widodo Winarso
}

\begin{abstract}
The success of education is reflected in the quality of high achieving graduates. There are many factors that influence student achievement of Tadris Matematika IAIN Sheikh Nurjati Cirebon as a candidate educator one of them is confidence attitude. Confidence is a form of readiness as an educator. On the basis of this researcher conducted research with descriptive correlational research method. Data collection instruments used were questionnaires, study documentation, and observation. The result of the research is the mean of the confidence level of students of Mathematics education IAIN Syekh Nurjati Cirebon is 69,36\% it means student selfconfidence level is high. The average achievement of student achievement of Mathematics IAIN Syekh Nurjati Cirebon is 3.32 shows the mean that the average achievement of students majoring in Mathematics education IAIN Syekh Nurjati Cirebon quite good. Based on Product Moment correlation test obtained a value of positive significance or equal to $67.7 \%$ means that there is a correlation between self-confidence in learning mathematics with the achievement of student learning Mathematics IAIN Syekh Nurjati Cirebon. Students 'selfconfidence level on learning presentation shows the higher the students'self-confidence the better the student's achievement of Mathematics.
\end{abstract}

Keywords: Prospective Mathematics Educator; Confidence; Learning achievement 


\begin{abstract}
Abstrak
Keberhasilan pendidikan tercermin dari mutu lulusan yang berprestasi tinggi. Terdapat banyak faktor yang mempengaruhi prestasi belajar mahasiswa Tadris Matematika IAIN Syekh Nurjati Cirebon sebagai calon pendidik salahsatunya yaitu sikap percaya terhadap diri sendiri. Kepercayaan diri merupakan salahsatu bentuk kesiapan untuk menjadi seorang pendidik. Atas dasar hal tersebut peneliti tertarik untuk melakukan penelitian. Metode penelitian yang digunakan adalah deskriptif korelasional. Instrumen pengumpulan data yang digunakan yaitu angket, study dokumentasi, dan observasi. Hasil penelitian yaitu rata-rata tingkat kepercayaan diri mahasiswa jurusan tadris Matematika IAIN Syekh Nurjati Cirebon adalah $69,36 \%$ artinya tingkat kepercayaan diri mahasiswa termasuk dalam kategori tinggi. Rata-rata perolehan prestasi belajar mahasiswa tadris Matematika IAIN Syekh Nurjati Cirebon adalah 3,32 menunjukan arti bahwa rata-rata prestasi belajar mahasiswa jurusan tadris Matematika IAIN Syekh Nurjati Cirebon termasuk dalam kategori baik. Berdasarkan uji korelasi Product Moment diperoleh nilai signifikansi bernilai positif atau sebesar $67,7 \%$ artinya bahwa terdapat korelasi antara kepercayaan diri mahasiswa terhadap prestasi belajar mahasiswa Matematika IAIN Syekh Nurjati Cirebon. Tingkat kepercayaan diri mahasiswa terhadap presatasi belajar menunjukan semakin tinggi kepercayaan diri mahasiswa maka semakin baik prestasi belajar mahasiswa Matematika.
\end{abstract}

Kata Kunci: Calon Pendidik Matematika; Kepercayaan Diri; Prestasi Belajar

\title{
Pendahuluan
}

Reformasi pendidikan dalam satu dekade terakhir menjadi prioritas pemerintah dalam pembangunan, diwujudkan dalam bentuk peningkatan anggaran dan belanja sektor pendidikan dari APBN dan APBD, serta peningkatan kesejahteraan pada para pendidik. Berbagai bentuk usaha pemerintah dilakukan untuk tercapainya kualitas pendidikan Indonesia yang semakin baik.Semakin berkembangnya tuntutan global maka peningkatan mutu sumber daya dan kualitas pendidikan perlu adanya peningkatan. Peningkatan mutu sumber daya manusia dan kualitas pendidikan dapat 
Korelasi Tingkat Kepercayaan Diri Terhadap Prestasi Belajar Mahasiswa Di IAIN Syekh Nurjati Cirebon (Studi Pada Calon Pendidik Matematika)

dilihat dari keberhasilan pada pendidikan formal, yaitu berupa prestasi belajar.

Matematika sebagai ilmu pengetahuan merupakan ilmu universal yang mendasari perkembangan teknologi modern, memajukan daya pikir manusia, dan mempunyai peran penting dalam berbagai displin ilmu (Yulianti, 2010). Sehingga Matematika perlu diajarkan kepada setiap manusia mulai dari pendidikan tingkat dasar sampai perguruan tinggi. Namun pada kenyataannya masih banyak mahasiswa tingkat dasar dan menengah yang memiliki anggapan bahwa Matematika ilmu yang paling sulit dipahami, sehingga mathematics as tool bagi manusia belum tercapai hal ini menyebabkan prestasi belajar mahasiswa Matematika kurang baik.

Berdasarkan hasil survei TIMSS yang diadakan mulai tahun 1999 dilakukan setiap 4 (empat) tahun, oleh The International Association for the Evaluation and Educational Achievement (IAE) berkedudukan di Amsterdam, mengambil fokus pada domain isi Matematika dan kognitif siswa. Domain isi meliputi Bilangan, Aljabar, Geometri, Data dan Peluang, sedangkan domain kognitif meliputi pengetahuan, penerapan, penalaran. Pada tahun 1999 Indonesia menempati posisi 34 dari 48 negara, tahun 2003 pada posisi 35 dari 46 negara, tahun 2007 pada posisi 36 dari 49 negara, dan pada tahun 2011 pada posisi 36 dari 40 negara. (Murtiyasa, 2015).

Keberadaan guru Matematika yang profesional merupakan kunci penting keberhasilan pendidikan Matematika di Indonesia. Salah satu strategi untuk mengahasilkan pendidik Matematika yang profesional yakni dengan mempersiapkan mahasiswa / calon pendidik Matematika dengan standar pendidik Matematika yang profesional.Dalam hal itu, pemerintah mulai menerapkan program Pendidikan Profesi Guru (PPG) bagi calon pendidik baru.

Standar guru Matematika yang profesional perlu di persiapkan di mulai dari mahasiswa calon pendidik Matematikayang mempunyai peranan yang sangat penting dalam pemenuhan kebutuhan pendidik Matematika 
yang profesional.Menurut Bostes \& Abdullah (2015:722) Bahwa calon guru adalah mahasiswa yang mengikuti program pada Lembaga Pendidikan Tenaga Kependidikan (LPTK). Sehingga calon guru Matematika adalah mahasiswa LPTK yang mengambil jurusan pendidikan Matematika. Calon guru memegang beberapa keyakinan tentang Matematika, mengajar dan belajar, tujuan mengajar, dan kemampuan dalam mengajarkan Matematika (Milgram, 2005).

Menurut UU Nomor 14 tahun 2005, guru yang profesional wajib memiliki 4 kompetensi, yaitu: “Kompetensi pedagogi, kompetensi kepribadian, kompetensi sosial, dan kompetensi profesional”.

Tetapi kenyataannya kebanyakan guru belum memiliki profesionalisme yang memadai untuk melaksanakan tugasnya sebagaimana yang tertuang dalam UU Nomor 20 Tahun 2003 Pasal 39, yaitu: “Merencanakan pembelajaran, menilai hasil pembelajaran, melakukan bimbingan, melakukan pelatihan, melakukan penelitian, dan melakukan pengabdian masyarakat”.

Ada tiga komponen yang harus dikuasai oleh mahasiswa calon guru Matematika untuk menjadi calon guru Matematika yang profesional, yaitu professional knowledge, professional practice, dan professional attitude(AITSL, 2011).

Professional knowledge merupakan pengetahuan profesional yang terdiri dari pengetahuan tentang materi/konten Matematika, teori belajar (pendekatan/model/metode/strategi belajar), kurikulum, dan penilaian. Secara garis besar, professional knowledge mencakup kompetensi profesional dan kompetensi pedagogik. Professional practice merupakan praktek profesional yang terdiri dari kemampuan mempersiapkan pembelajaran yang tertuang dalam rencana pelaksanaan pembelajaran dan performa mengajar (microteaching/PPL). Professional attitude merupakan sikap profesional yang terdiri dari beliefs mahasiswa untuk menjadi guru Matematika yang profesional dan persepi mahasiswa tentang dirinya, siswa, kolega, serta profesi sebagai guru Matematika. 
Korelasi Tingkat Kepercayaan Diri Terhadap Prestasi Belajar Mahasiswa Di IAIN Syekh Nurjati Cirebon (Studi Pada Calon Pendidik Matematika)

Salah satu perguruan tinggi yang memiliki tugas utama menyelenggarakan pendidikan dan pengajaran dalam bidang pendidikan Matematika yaitu Institut Agama Islam Negeri (IAIN) Syekh Nurjati Cirebon yang di beri nama Tadris Matematika, output dari proses pembelajaran tersebut adalah calon pendidik Matematika. Dari hasil pengamatan beberapa mahasiswa jurusan Tadris Matematika, terdapat banyak faktor yang diidentifikasi berpengaruh terhadap prestasi belajar mahasiswa yaitu kekurang yakinan atau rendahnya percaya diri pada kemampuan yang dimiliki terlihat ketika presentasi, mengerjakan latihan, tugas, bahkan ketika ujian seperti kuis, ujian tengah semester dan ujian akhir semester. Hal tersebut dapat mempengaruhi performa ketika menjadi seorang pendidik dalam berinteraksi dengan siswa dan lingkungan sekitarnya.

MenurutPermendiknas RI No 16 tentang StandarKualifikasi Akademik dan Kompetensi Guru (2007) bahwa: "Rasa percaya diri disamakandengan istilah "keyakinan guru”, yang artinya sikap mental yang dimiliki guruterhadap manfaat Matematika bagi siswa, dirinya, dan kehidupan seharihari, sertakeyakinan akan kemampuan dirinya dalammengajar Matematika”.

Menurut Hannula, Maijala \& Pehkonen (2004) Salah satu faktor yang berpengaruh terhadap proses dan hasil belajar Matematika adalah faktor internal yakni self-belief. Keyakinan (belief) terhadap diri sendiri memiliki hubungan yang luar biasa dengan kesuksesan siswa dalam belajar Matematika. Keyakinan yang dimiliki siswa dalam belajar Matematika tidak sesuai dengan fakta yang ada. Hasil studi TIMSS dalam Adhetia (2013) yang menyatakan siswa di Indonesia hanya 3\% siswa yang memiliki selfconfidence tinggi dalam Matematika, sedangkan 52\% termasuk dalam kategori siswa dengan self-confidence sedang dan $45 \%$ termasuk dalam kategori siswa dengan self-confidence rendah. Hal tersebut menunjukan bahwa masih banyak siswa yang memiliki self-confidence rendah.

Keberhasilan pendidikan tercermin dari mutu lulusan yang berprestasi tinggi. Untuk mendapat prestasi yang tinggi mahasiswa Tadris Matematika 
IAIN Syekh Nurjati Cirebon sebagai calon pendidik dipengaruhi oleh banyak faktor yang memiliki hubungan yang signifikan dengan prestasi belajar mahasiswa yaitu kepercayaan diri mahasiswa sebagai bentuk kesiapan dalam menghadapi tantangan dan mencoba sesuatu yang baru di dunia yang baru dan profesi yang baru sebagai seorang pendidik. Sehingga Peneliti tertarik untuk mengkaji tentang “Korelasi Tingkat Kepercayaan Diri Terhadap Prestasi Belajar Mahasiswa (Calon Guru Matematika) IAIN Syekh Nurjati Cirebon."

\section{Metode Penelitian}

Penelitian ini dilakukan di Jurusan Tadris Matematika Fakultas IImu Tarbiyah dan Keguruan Kampus IAIN Syekh Nurjati Cirebon Jalan Perjuangan By Pass Sunyaragi Cirebon 45132. Metode deskriptif korelasional dan pendekatan penelitian kuantitatif digunakan untuk mengetahui dan memperoleh data atau informasi yang akurat tentang korelasi tingkat kepercayaan diri terhadap prestasi belajar mahasiswa (calon pendidik Matematika) di IAIN Syekh Nurjati Cirebon. Populasi umum dalam penelitian ini adalah Fakultas IImu Tarbiyah dan Keguruan IAIN Syekh Nurjati Cirebon. Adapun populasi target berdasarkan masalah penelitian ini yaitu Mahasiswa Tadris Matematika IAIN Syekh Nurjati Cirebon 2015/2016. Teknik pengambilan sampel yang digunakan adalah Proportionate stratified random sampling.

Tabel 1 Sampel Penelitian

\begin{tabular}{|c|c|c|c|c|}
\hline No & $\begin{array}{c}\text { Semester- } \\
\text { Kelas }\end{array}$ & LK & PR & $\begin{array}{c}\text { Jumlah } \\
\text { Siswa }\end{array}$ \\
\hline 1 & $2-B$ & 10 & 28 & 38 \\
\hline 2 & $4-C$ & 6 & 29 & 35 \\
\hline 3 & $6-A$ & 11 & 21 & 32 \\
\hline \multicolumn{2}{r|}{ Jumlah } & 27 & 78 & 105 \\
\hline
\end{tabular}

Teknik pengumpulan data pada penelitian ini adalah angket, observasi dan studi dokumentasi. Angket digunakan untuk mengukur tingkat kepercayaan diri mahasiswa (calon pendidik matematika), observasi 
Korelasi Tingkat Kepercayaan Diri Terhadap Prestasi Belajar Mahasiswa Di IAIN Syekh Nurjati Cirebon (Studi Pada Calon Pendidik Matematika)

digunakan untuk untuk mengetahui masalah yang ada di sekolah pada saat penelitian pendahuluan, dan sebagai pendukung hasil angket yang telah dilakukan pada saat penelitian, dan dtudi dukumentasi digunakan untuk mengumpulkan daftar nilai Indeks Prestasi (IP) mahasiswa tadris Matematika tahun 2016/2017. Intrument dalam angket penelitian ini disusun berdasarkan indikator variabel penelitian. Berdasarkan skala Likert (pernyataan selalu, sering, pernah, dan tidak pernah).

\section{Hasil Penelitian dan Pembahasan}

Hasil penelitian ini merupakan hasil yang diperoleh dari Mahasiswa Tadris Matematika Fakultas Tarbiyah dan Ilmu Keguruan IAIN Syekh Nurjati Cirebon. Hal ini dimaksudkan sebagai bahan pembuktian yang bersifat studi terhadap usaha nyata ada tidaknya korelasi tingkat kepercayaan diri terhadap prestasi belajar mahasiswa pendidikan Matematika. Berikut ini disajikan lebih jelas dan terperinci laporan hasil penelitian ini berdasarkan sumber data yang didapatkan.

Adapun hasil penyebaran angket terhadap respon tingkat kepercayaan diri mahasiswa di kelas digambarkan pada tabel di bawah ini:

\section{Tabel 2 Distribusi Frekuensi Tingkat Kepercayaan Diri Mahasiswa Berdasarkan Kriteria Nilai Angket}

\begin{tabular}{|c|c|c|c|}
\hline Skor & Kriteria & $F$ & Peringkat \\
\hline $0-20$ & Sangat lemah & 0 & 5 \\
\hline $21-40$ & Lemah & 0 & 4 \\
\hline $41-60$ & Cukup & 15 & 3 \\
\hline $61-80$ & Kuat & 80 & 2 \\
\hline $81-100$ & Sangat Kuat & 10 & 1 \\
\hline \multicolumn{2}{|c|}{ Jumlah } & 105 & \\
\hline
\end{tabular}

Perhitungan pada tabel 2 di atas, dapat diketahui bahwa perolehan sikap tingkat kepercayaan diri mahasiswa dengan perolehan terbanyak pada skor 61 sampai 80 sebanyak 80 mahasiswa. Dapat dikatakan bahwa sikap mahasiswa terhadap kepercayaan diri tergolong kuat berdasarkan kriteria 
menurut Riduwan. Terdapat 10 mahasiswa yang memiliki sikap tingkat kepercayaan sangat kuat.

Tabel 3 Descriptive Statistics

\begin{tabular}{|c|c|c|c|c|c|c|}
\hline & N & Min & Max & Sum & Mean & Std. Deviation \\
\hline $\begin{array}{c}\text { Tingkat Kepercayaan } \\
\text { Diri Mahasiswa }\end{array}$ & & 54 & 100 & 7283 & 69,36 & 8,022 \\
\hline Valid N (listwise) & 105 & & & & & \\
\hline
\end{tabular}

Berdasarkan tabel 3jumlah responden sebanyak 105 mahasiswa. Setelah angket tingkat kepercayaan diri mahasiswa disebarkan kepada mahasiswa, maka didapat skor mean sebesar 69,36\% yang artinya tingkat kepercayaan diri mahasiswa mahasiswa secara keseluruhan memiliki rata-rata sebesar 69,36\% dan tingkat kepercayaan diri mahasiswa tersebut tergolong dalam kategori kuat.

Nilai minimum yang didapat sebesar 54 yang artinya skor tingkat kepercayaan diri mahasiswa mahasiswa yang terkecil secara keseluruhan adalah sebesar 54. Skor tingkat kepercayaan diri mahasiswa yang terbesar secara keseluruhan sebesar 100, sedangkan jumlah total nilai sebesar 7283.

Data prestasi belajar mahasiswa diperoleh dari hasil nilai indeks prestasi mahasiswa tadris Matematika pada semester 1, 3 dan 5 tahun ajaran 2016/2017. Dari data yang didapatkan diperoleh suatu deskripsi sebagai berikut:

Tabel 4 Frekuensi Indeks Prestasi Belajar Mahasiswa

\begin{tabular}{|c|c|c|c|c|}
\hline Interval Nilai IP & Jumlah & Presentase & Peringkat & Ket \\
\hline $3,75-4$ & & & A & Baik Sekali \\
\hline $2,75-3,74$ & 105 & 100 & B & Baik \\
\hline $2-2,74$ & & & C & Cukup \\
\hline $1-1,99$ & & & D & Kurang \\
\hline $0-0,99$ & & & E & Gagal \\
\hline
\end{tabular}

Berdasarkan tabel 4 di atas, diketahui bahwa 105 mahasiswa yang memperoleh indeks prestasi antara 2,75 hingga 3,74 atau setara dengan $100 \%$ mahasiswa tadris matematika memiliki prestasi belajar yang termasuk 
Korelasi Tingkat Kepercayaan Diri Terhadap Prestasi Belajar Mahasiswa Di IAIN Syekh Nurjati Cirebon (Studi Pada Calon Pendidik Matematika)

dalam kategori 'B' yaitu Baik. Hal itu menunjukan secara umum mahasiswa tadris matematika dapat mengikuti perkuliahan dengan baik untuk setiap mata kuliah.

Data penelitian prestasi belajar mahasiswa Matematika juga telah dikelompokkan berdasarkan nilai bobot dan nilai huruf (nilai mutu). Hasil pengelompokan data prestasi belajar dapat dilihat melalui tabel di bawah ini:

Tabel 5 Deksripsi Statistik Prestasi Belajar Mahasiswa Matematika

\begin{tabular}{|l|c|c|}
\hline & $\begin{array}{c}\text { Prestasi Belajar Mahasiswa } \\
\text { Matematika }\end{array}$ & $\begin{array}{c}\text { Valid N } \\
\text { (listwise) }\end{array}$ \\
\hline $\mathrm{N}$ & 105 & 105 \\
\hline Range & .91 & \\
\hline Minimum & 2.70 & \\
\hline Maximum & 3.61 & \\
\hline Mean & 3.3286 & \\
\hline Std. Deviation & .16354 & \\
\hline Variance & .027 & \\
\hline
\end{tabular}

Berdasarkan tabel 5 mengenai deskripsi prestasi belajaar mahasiswa Matematika diketahui dari 105 mahasiswa diperoleh rata-rata sebesar 3,32, standar deviasi sebesar 0,16354, variansi sebesar 0,027, nilai minimum sebesar 2,70, nilai maksimum sebesar 3,61 dan range sebesar 0,91. Untuk mengetahui gambaran perolehan frekuensi indeks prestasi mahasiswa berdasarkan kelompok dapat dilihat melalui tabel berikut.

Tabel 6 Frekuensi Indeks Prestasi Belajar Mahasiswa

\begin{tabular}{|c|c|c|c|}
\hline Indeks Prestasi & Interval & Jumlah & Presentase \\
\hline A & 4,00 & & \\
\hline A- & $3,75-3,99$ & & \\
\hline B+ & $3,25-3,74$ & 78 & 74,2 \\
\hline B & $3,0-3,24$ & 23 & 22 \\
\hline B- & $2.75-2,99$ & 4 & 3,8 \\
\hline C+ & $2,5-2,74$ & & \\
\hline C & $2,25-2,49$ & & \\
\hline C- & $2,0-2,24$ & & \\
\hline D & $1,0-1,99$ & & \\
\hline E & $0-0,99$ & & \\
\hline \multicolumn{2}{|c|}{ Total } & 105 & $100 \%$ \\
\hline
\end{tabular}


Berdasarkan tabel 6 di atas, diketahui bahwa terdapat 4 mahasiswa yang memperoleh indeks prestasi antara 2.75 hingga 2.99 atau setara dengan (3.8\%), terdapat 23 mahasiswa yang memperoleh indeks prestasi antara 3.00 hingga 3.24 atau setara (22\%) dan terdapat 78 mahasiswa yang memperoleh indeks prestasi antara 3.25 hingga 3.74 atau setara dengan (74.2\%). Sehingga dapat diketahui presentase terbanyak (74.2\%) mahasiswa memiliki indeks pretasi antara 3.25 hingga 3.74 .

Uji Korelasi yang digunakan adalah uji Keofisein Korelasi Product Momentuntuk mengetahui kesesuaian antara hipotesis. yang telah dirumuskan dengan hasil data yang didapat dari penelitian. untukmenguji hipotesis dalam penelitian ini, peneliti menggunakan rumus Product Moment dengan bantuan SPSS 21. Kriteria pengujiannya adalah:

(a) thitung > ttabel maka $\mathrm{H}_{0}$ ditolak dan $\mathrm{H}_{\mathrm{a}}$ diterima

(b) thitung < ttabel maka $\mathrm{H}_{0}$ diterima dan $\mathrm{H}_{\mathrm{a}}$ ditolak.

Berdasarkan perhitungan menggunakan SPSS diperoleh hasil perhitungan sebagai berikut:

Tabel 7 Uji Korelasi Tingkat Kepercayaan Diri Mahasiswa Matematika terhadap Prestasi Belajar Mahasiswa Matematika

\begin{tabular}{|c|c|c|c|}
\hline \multicolumn{4}{|c|}{ Correlations } \\
\hline & & $\begin{array}{c}\text { Kepercayaan } \\
\text { Diri }\end{array}$ & Prestasi Belajar \\
\hline \multirow{3}{*}{ Kepercayaan Diri } & Pearson Correlation & 1 & $.677^{*}$ \\
\hline & Sig. (2-tailed) & & .000 \\
\hline & $\mathrm{N}$ & 105 & 105 \\
\hline \multirow{3}{*}{ Prestasi Belajar } & Pearson Correlation & $.677^{* *}$ & 1 \\
\hline & Sig. (2-tailed) & .000 & \\
\hline & $\mathrm{N}$ & 105 & 105 \\
\hline
\end{tabular}

Dari hasil tabel 7 diatas dapat diketahui korelasi antara tingkat kepercayaaan diri mahasiswa terhadap presatsi belajar mahasiswa Matematika pada semester II, IV, VI tahun ajaran 2016/2017 ganjil. Besarnya korelasi antara antara tingkat kepercayaaan diri mahasiswa terhadap presatsi belajar mahasiswa Matematika diperoleh besarnya korelasi adalah 0,677. 
Korelasi Tingkat Kepercayaan Diri Terhadap Prestasi Belajar Mahasiswa Di IAIN Syekh Nurjati Cirebon (Studi Pada Calon Pendidik Matematika)

Dikarenakan nilai korelasi positif maka terjadi adanya korelasi searah dalam penelitian ini.

Setelah megetahui besarnya koefisien korelasi, maka perlu dilakukan pengujian hipotesis untuk megetahui apakah korelasi tersebut berarti atau tidak. Uji hipotesis dapat dinyatakan dengan membandingkan nilai signifikan yaitu:

Jika nilai probabilitas $>0,05$, maka $\mathrm{H}_{0}$ diterima

Jika nilai probabilitas $<0,05$, maka $\mathrm{H}_{0}$ ditolak

Berdasarkan hasil uji korelasi di atas nilai signifikan sebesar 0,000. Karena nilai signifikan lebih kecil dari 0,05 maka Ho ditolak, artinya Terdapat hubungan tingkat kepercayaan diri dengan prestasi belajar mahasiswa. Seperti yang sudah dijelaskan sebelumnya bahwa besarnya korelasi adalah sebesar 0,677 atau kisaran 67,7\%.

Hasil perhitungan diatas disimpulkan bahwa terjadi adanya korelasi prestasi belajar Matematika dengan tingkat kepercayaan diri mahasiswa. Dengan kata lain, semakin tinngi tingkat kepercayaan diri mahasiswa maka semakin baik presatasi belajat mahasiswa Matematika.

Uji Chi Kaudrat dilakukan untuk mengetahui kesesuaian antara hubungan tingkat kepercayaan diri terhadap prestasi belajar mahasiswa matematika yang telah dirumuskan dengan hasil data yang didapat dari penelitian untuk menguji hipotesis dalam penelitian ini, peneliti menggunakan rumus Chi Kuadrat dengan bantuan SPSS 21. Kriteria pengujiannya adalah $\mathrm{x}^{2}$ hitung $\geq \mathrm{x}^{2}$ tabel, maka tolak $\mathrm{HO}$ artinya signifikan. Perhitungan hasil SPSS sebagai berikut: 
Tabel 8 Uji Chi Kuadrat Tingkat Kepercayaan Diri Mahasiswa * Prestasi Belajar Matematika Crosstabulation

\begin{tabular}{|c|c|c|c|c|c|}
\hline \multicolumn{2}{|c|}{} & \multicolumn{3}{c}{$\begin{array}{c}\text { Prestasi Belajar } \\
\text { Matematika }\end{array}$} & \multirow{2}{*}{ Total } \\
\cline { 2 - 6 } \multicolumn{2}{|c|}{} & B- & B & B+ & \\
\hline \multirow{2}{*}{$\begin{array}{c}\text { Tingkat } \\
\text { Kepercayaan } \\
\text { Diri } \\
\text { Mahasiswa }\end{array}$} & Cukup & 4 & 11 & 0 & 15 \\
\cline { 2 - 6 } & Kuat & 0 & 12 & 68 & 80 \\
\hline \multicolumn{2}{|c|}{ Total } & 0 & 0 & 10 & 10 \\
\hline
\end{tabular}

Dari hasil tabel 8 diatas dapat diketahui tingkat kepercayaan diri mahasiswa terhadap presatsi belajar mahasiswa Matematika pada semester II, IV, VI tahun ajaran 2016/2017 ganjil. Tingkatan kepercayaan diri tersebar dalam kategori cukup, kuat dan sangat kuat sedangkan besarnya prestasi belajar mahasiswa terdapat pada sebaran B-, B dan B+.Dari hasil perhitungan diatas diketahui tingkat kepercayaan diri cukup dimiliki oleh 4 mahasiswa yang memiliki prestasi belajar B- dan 11 mahasiswa B, untuk tingkat kepercayaan diri kuat dimiliki oleh 12 mahasiswa dengan prestasi belajar B dan 68 mahasiswa dengan prestasi belajar $\mathrm{B}+$ sedangkat untuk mahasiswa yang memiliki tingkat kepercayaan diriyang sangat kuat dimiliki oleh 10 mahasiswa dengan prestasi belajar B+. Dapat disimpulkan bahwa semakin tinggi tingkat kepercayaan diri mahasiswa maka semakin baik prestasi belajar mahasiswa Matematika.

\section{Simpulan dan Saran}

Berdasarkan hasil penelitian yang dilakukan mengenai korelasi tingkat kepercayaan diri terhadap prestasi belajar mahasiswa (calon pendidik) Matematika IAIN Syekh Nurjati Cirebon, peneliti dapat menyimpulkan berdasarkan rumusan masalah. Adapun kesimpulan penelitian sebagai berikut:1) Tingkat kepercayaan diri mahasiswa Matematika IAIN Syekh Nurjati tergolong kuat, artinya mahasiswa Matematika telah memiliki kesiapan sebagai calon seorang pendidik; Hal tersebut bisa dilihat melalui 
Korelasi Tingkat Kepercayaan Diri Terhadap Prestasi Belajar Mahasiswa Di IAIN Syekh Nurjati Cirebon (Studi Pada Calon Pendidik Matematika)

data hasil perolehan angket secara keseluruhan dengan nilai rata-rata sebesar $69,36 \%$, nilai minimum sebesar 54, dan maksimum sebesar 100;2)Prestasi belajar mahasiswa Matematika IAIN Syekh Nurjati Cirebon tergolong dalam kategori B (Baik), artinya mahasiswa matematika dapat mengikuti perkuliahan dengan baik untuk setiap mata kuliah. Hal ttersebut bisa dilihat melalui data nilai IP semester ganjil dari jumlah sampel 105 mahasiswa diketahui indeks prestasi antara 2,75 hingga 3,74 dengan rata-rata sebesar 3,32; 3)Terdapat korelasi tingkat kepercayaan diri terhadap prestasi belajar mahasiswa Matematika sebesar 0,677 atau $67,7 \%$ artinya korelasi positif antara kepercayaan diri terhadap pembelajaran Matematika terhadap nilai prestasi belajar mahasiswa Matematika IAIN Syekh Nurjati Cirebon. Semakin tinggi tingkat kepercayaan diri semakin baik prestasi belajar mahasiswa Matematika.

Oleh karena itu, dapat simpulkan adanya korelasi kepercayaan diri terhadap prestasi belajar mahasiswa Matematika IAIN Syekh Nurjati Cirebon. Korelasi termasuk dalam kategori kuat. Oleh karena itu, perlu adanya upaya untuk meningkatkan kepercayaan diri mahasiswa Matematika salah satunya adalah membiasakan diri mengerjakan tugas dan ujian semaksimal mungkin dengan apa adanya dan sebaiknya mahasiswa tidak ditakuti oleh standar nilai kelulusan yang begitu tinggi pada salah satu mata kuliah yang ada. Hal ini dilakukan untuk melatih tingkat kepercayaan diri mahasiswa agar lebih mandiri dalam mengikuti segala proses pembelajaran atau perkuliahan.

Adapun saran yang dapat peneliti berikan berdasarkan hasil penelitian korelasi tingkat kepercayaan diri terhadap prestasi belajar mahasiswa Matematika IAIN Syekh Nurjati Cirebon adalah sebagai berikut:

Bagi para pendidik, khususnya dosen Matematika untuk dapat mengembangkan kemampuannya dengan memberikan pembelajaran yang lebih bervariatif dalam mengeksplore kemampuan yang dimiliki oleh mahasiswa sebagai salah satu upaya meningkatkan rasa kepercayaan diri sebagai calon seorang pendidik. Sebaiknya dilakukan penilaian aspek afektif 
pada mahasiswa guna memperoleh informasi tambahan untuk menyuksekan mahasiswa sebagai calon pendidik yang memiliki moral islami yang tinggi. Bagi para mahasiswa, untuk meningkatkan kepercayaan diri mahasiswa Matematika salah satunya adalah membiasakan diri mengerjakan tugas dan ujian semaksimal mungkin dengan apa adanya dan sebaiknya mahasiswa tidak ditakuti oleh standar nilai kelulusan yang begitu tinggi pada salah satu mata kuliah yang ada. Mahasiswa juga sebaiknya selalu siap ketika ditunjuk dan berani tampil di depan dengan segala kemampuan yang dimiliki. Hal ini dilakukan untuk melatih tingkat kepercayaan diri mahasiswa agar lebih mandiri dalam mengikuti segala proses pembelajaran atau perkuliahan Bagi peneliti selanjutnya, diharapkan agar dapat melakukan penelitian lain dengan metode yang berbeda seperti, menggunakan metode kualitatif ataupun campuran untuk mengetahui dan mendapatkan informasi yang lebih akurat dan beragam mengenai psikologi belajar Matematika yang mendasari tingkat kepercayaan diri mahasiswa Matematika tinggi.

\section{Daftar Pustaka}

Abdullah, S. S. (2015). Mahasiswa (Calon) Guru Matematika yang Profesional. In Prosiding Seminar Nasional Matematika dan Pendidikan Matematika. Jurusan Pendidikan Matematika FMIPA UNY.

Adhetia, M. (2013). Membangun Self-Cofidence Siswa Dalam Pembelajaran Matematika Dengan Pendekatan Problem Solving. In Prosiding Seminar Nasional Matematika dan Pendidikan Matematika. Jurusan Pendidikan Matematika FMIPA UNY.

Departemen Pendidikan Nasional. (2008). Penilaian kinerja guru. Jakarta: Direktoral Jenderal Peningkatan Mutu Pendidik dan Tenaga Kependidikan Departemen Pendidikan Nasional.

Bahri, D. S. (1994). Prestasi Belajar dan Kompetensi Guru. Surabaya: Usaha Nasional.

Forgasz, H. J., \& Hill, J. C. (2013). Factors implicated in high mathematics achievement. International Journal of Science and Mathematics Education, 11(2), 481-499 
Korelasi Tingkat Kepercayaan Diri Terhadap Prestasi Belajar Mahasiswa Di IAIN Syekh Nurjati Cirebon (Studi Pada Calon Pendidik Matematika)

Hannula, M. S., Maijala, H., \& Pehkonen, E. (2004). Development Of Understanding and Self-Confidence In Mathematics; Grades 5-8. In Proceedings of the 28th Conference of the International (Vol. 3, pp. 17-24).

Margono, S. (2005). Metodologi Penelitian Pendidikan. Jakarta: PT. Rineka Cipta.

McLeod, D. B., \& McLeod, S. H. (2002). Synthesis-beliefs and mathematics education: Implications for learning, teaching, and research. Mathematics Education Library, 31, 115-126.

Murtiyasa, B. (2015). Tantangan pembelajaran matematika era global. Paper presented in Seminar Nasional HUT FKIP Matematika UMS ke 31.

Presmeg, N. (2002). Beliefs About the Nature of Mathematics in the Bridging of Everyday and School Mathematical Practices. In Beliefs: A Hidden Variable in Mathematics Education?(pp. 293-312). Springer Netherlands.

Salam, B. (2004). Cara belajar yang sukses di perguruan tinggi. Jakarta: PT. Rineka Cipta.

Santrock, John. (2003). Perkembangan Remaja. Jakarta : Erlangga.

Toheri, T.,\& Winarso, W. (2017). Mathematical Thinking Undefended on The Level of The Semester for Professional Mathematics Teacher Candidates. University Library of Munich, Germany.

Yulianti, E., Zulkardi, Z., \& Siroj, R. A. (2010). Pengembangan Alat Peraga Menggunakan Rangkaian Listrik Seri-Paralel Untuk Mengajarkan Logika Matematika Di SMK Negeri 2 Palembang. Jurnal Pendidikan Matematika, 4(1), 25-32.

\section{Uun Badriyah}

IAIN Syekh Nurjati Cirebon, Jalan perjuangan By Pass Sunyaragi

Email : uunbadriyah7@gamil.com

\section{Widodo Winarso}

IAIN Syekh Nurjati Cirebon, Jalan perjuangan By Pass Sunyaragi

Email : widodoiain@gmail.com 